\title{
Eukaryotic Translation Initiation Factor 4B
}

National Cancer Institute

\section{Source}

National Cancer Institute. Eukaryotic Translation Initiation Factor 4B. NCI Thesaurus.

Code $\mathrm{C121145.}$

Eukaryotic translation initiation factor 4B (611 aa, $69 \mathrm{kDa})$ is encoded by the human

EIF4B gene. This protein plays a role in the initiation of translation through promoting the binding of mRNA to ribosomes. 